\title{
Language Planning and Policy in the Education System of Bangladesh
}

\author{
Mohammad Rukanuddin \\ Department of Arts and Sciences, Ahsanullah University of Science and Technology \\ 141-142 Love Road, Tejgaon, Dhaka 1208, Bangladesh
}

\begin{abstract}
This paper explores in a miniature scale what language planning and language policy are, and the impact they have had on the education system of Bangladesh. In doing so, certain sociolinguistic aspects like choosing of national language, official language, how to adopt language policy and planning have been dealt with. It discusses the current condition of the English language teaching and learning in Bangladesh with reference to its history since the independence of the country. It has emphasized upon the role of teachers, students, specialists and researchers so that appropriate planning and policy can be drawn regarding English teaching and learning in the country. It includes a couple of suggestions regarding the issue.
\end{abstract}

Keywords: language planning, language policy, national language, and second language

DOI: $10.7176 / \mathrm{JEP} / 10-14-11$

Publication date:May $31^{\text {st }} 2019$

\section{Introduction}

Every country should have her own planning and policy regarding how to choose her national language, official language, and second language etc., in order to facilitate the smooth communication among the people inside the national boundary as well as with the people of other countries of the world. This selection of language has a long lasting and deep rooted impact on the education of the citizens of a county. Regarding language planning Rubin and Jernudd (1971) say,

"Language planning is deliberate language change; that is, changes in the system of language code or speaking or both that are planned by organizations that are established for such purposes or given a mandate to fulfill such purposes......for solving language problems to find the best (or optimal, most efficient) decision" (p 29).

So, it can be said that language planning is an official activity of a government which is concerned with the selection and promotion of a common language or other languages.

According to Arzoz (2007), language policy is a government's action taken officially or by making law to find out how languages are to be used. It also looks at cultivating the skills of languages required for national priority or establishing the individual or group's rights for using and maintaining languages. This may be explained by the fact that language policy is often based on socio-historical reasons.

Language policy and planning is needed for meeting certain sociological requirements. Robinson (1988) in this regard has pointed out that if there are a number of linguistic groups competing for right to use the amenities of daily life, and a certain linguistic minority is deprived of access to such amenities, language planning and policy are required.

A nation's identity as a country is fostered through its language planning and policy. The prosperity of a country largely relies upon the language policy and strategy. The right use of language must be ensured for the greater welfare of the younger generation. All should strictly follow the rules and regulation of the language policy and planning. In this regard, the role of teachers, students, and linguists cannot be denied. Therefore, the national language of a country, like Bangladesh has its own prestige and reputation in this sense that many valiant sons of the country including Salam, Rafiq, Barkat, and Jabber have sacrificed their lives during the Language Movement of 1952.

However, to define a national language, Holmes (2001) says, "A national language is the language of a political, cultural and social unit". That means it is usually developed and used as a sign of national solidarity. She adds, "An official language, by contrast, is simply a language which may be used for government business." She is also of the opinion that it is not impossible for one language to serve both the functions.

The decisions on language planning issue normally attempt to meet the requirements of establishing 'national unity' and performing 'government business.' These requirements are met by reducing linguistic diversity, for instances, when a single language is declared a national language in a multilingual country (such as Bahasha Indonesia in Indonesia), or when a single variety of a language is declared 'standard' to promote linguistic unity in a country where divergent dialects exist. David (2006) says, "For example, although many dialects of Chinese exist, the promotion of a single variety 'Mandarin', as a national language, contributes to a sense of national unity". In Bangladesh, there is a language policy on the basis that Bangla has been declared a national language. Despite the fact that Bangla is the national language of Bangladesh, English is used in both 
private and government institutions extensively. But, there is no specific policy regarding the teaching and learning of English. This lacking results in the deterioration of the learning and teaching of English in the country.

Since the national language of a country helps its nation develop economically, politically, communally, and socially, as citizens of the country, the people of Bangaldesh must try to protect the dignity of the language. Based upon the national language, many litterateurs, scientists, engineers, and many more write regarding various aspects of knowledge. The citizens should all pay heed to their deeds and contributions. Some of the noted intellectuals: What Kazi Nazrul Islam and Rabindranath Tagore have written on the Bengali language cannot be denied. The whole nation will owe to them. Nevertheless, the people should be aware whether they should any other language for the greater benefits of the natiaon. Moreover, they should keep in mind that accepting any other language as a second language does not show any dishonor to one's natioal language.

\section{Literature Review}

Selection of languages as official or national should be done prudently as it is an emotive and political issue. According to Holmes (2001), selection of the language to be made as national or official language is usually a fully political decision, although linguistic experts might point out the different linguistic problems created by selecting one variety rather than another variety. She adds that accepting a language by the people normally needs support by politicians and socially respected groups.

For political and emotional reasons different countries take different decisions. Some countries have chosen one language as official language and two languages as national languages; some countries have chosen two languages as official languages and one as national language. In a country which is a monolingual country it is not difficult to choose a national language. But, in a multilingual country, the country has to resort to one or two foreign languages for its communicative functions.

Cooper (1989), Schiffman (1996), and Kaplan and Baldauf (2003) have argued that language policy and language planning are two different conceptions: language policy is about making decision and setting goal; language planning is about implementation of policies to get results. On the contrary, Rubin (1971) has argued that language policy is a part of language planning. According to her, language planning is comprising of four phases: finding fact, determination of policy, execution, and evaluation.

According to Weinstein (1980) "language planning is a government authorized, long term, sustained, and conscious effort to alter a language's role in a society for the purpose of solving communication problems."

Hamid \& Elizabeth (2016) have suggested that teaching and learning of English have not produced desirable results in Bangladesh especially in the secular government schools and madrasas where most of the students study. They add that both teachers and students in the country have poor levels of English proficiency. They have also said, "majority of teachers are teaching students at higher levels than their own ability in the language". They have pointed out that one of the reasons that hinder the making of a policy of English language education in Bangladesh is the politics that surrounds the national language Bangla.

\section{Stages of Language Planning}

Language planning process includes typically three stages. The first stage is a needs analysis, involving a sociopolitical analysis of communication needs with the people living in the society or community. The next stages involve the selection of a language or language variety for planning purposes. These stages are sometimes referred to as 'status planning' and includes - a) Codification - it means establishing the characteristics or criteria of a 'good language.' b) Standardization - it means establishing a unified variety of language, if necessary.

Moreover, 'fine tuning 'the selected language or language variety which is referred to as 'corpus planning' may also be required. This corpus planning includes the following stages: i) Elaboration: It is a kind of various developments that include vocabulary and stylistic mechanisms expansion, and creating fonts of type that allow language to work in a bigger linguistic functional arena. ii) Cultivation: It is the establishment of arbiters, such as dictionaries or language academies, which maintain and develop the status of the language. (Visit: https://www.ericdigests.org/pre-9210/planning.htm)

To make the best use of language planning and policy, the users of the concerned language must be conscious of vocabulary, syntax, idiom and phrase, clause, spelling, punctuation marks and capitalization. If teachers try utmost to teach the fundamental rules of grammar from the very early stage of education planning and policy, younger learners must be conversant with the grammatical rules. They must have a regular practice of what they want to write creatively and critically. Through the language identity, the career of a person is built up. In this situation, language specialists, linguists, and experts ought to come forward with a view to motivating the younger generation of the country. 


\section{Language Planning and Policy in Bangladesh}

In Bangladesh since its independence in 1971, Bangla has been the officially declared state language or national language though Bangladesh is a near monolingual country. In spite of being the state language, Bangla was not being used at all fields. Rather English continued to be used in many government offices, semi government offices, educational institutions, banks, private sector businesses, and even in law courts of the country. Subsequently, on 12 March 1975 there was an official order saying that Bangla must be used in all government offices strongly discouraging the use of English (Mahbub, 2015).

Because of this order, Bangla started to be used in majority of the official jobs, but not all levels. As a result, in 1978 a decision was adopted by the cabinet of ministers that Bangla must be used in all walks of life. Nonetheless, this order was of no use. In 1978 Bangla language implementation act was passed by the government. This law made it mandatory for the people working in the government, semi government and autonomous bodies to use Bangla in inter-office communication, legal documents and communication except in case of correspondences with foreign nations and organizations (Rahman 1999).

As Bengali is the only national language, the Bangladesh people learn to fulfill their long awaited-dream through this language. Bengali, as the national language, plays a significant role in the identity of Bangladeshi people. Many poets, novelists, story writers, and treatise writers have contributed their valuable works in this language. As citizens of the country, it is their duty and responsibility to develop Bengali language by all means but not closing door for any other important language.

\subsection{Decline of English in Education Sector}

With the implementation of Bangla introduction law in the country, the people all over the country began to use Bangla in almost all walks of life. Because of this law, English assumed the status of a foreign language losing its previous position of second language that it enjoyed during the Pakistani rule. The effect of this change became conspicuous in the field of education. According to Rahman (1999), "English was no longer a medium of instructions and adequate attention to the teaching of English was not given at lower levels. Paradoxically, more than $90 \%$ of text books at higher levels of study continued to be in English. More and more students were coming to the University for Higher Studies with an inadequate command of English."

Moreover, regarding English the constitution of Bangladesh does not say anything. According to Bangladesh Constitution: "The state language of the Republic is Bangla." The constitution terms English as neither second language nor official language. As a result, there is no clear policy regarding the status of English in the country though it has been learnt and used by many people with the importance of a second language. Crystal (1995) has mentioned that there is no official status of English in Bangladesh, but is continuously being used for international communication. Kachru (1981) and Jernudd (1981) have had a belief that as Bangladesh has no formal announcements regarding English in her 'language policy plans', it is difficult to ascertain a precise place for the English language or its improvement in Bangladesh. Regarding the condition of English in Bangladesh Kachru (1996) even has said that in Bangladesh, "English seems to be experiencing life after neardeath".

Though English is not the official language of Bangladesh, yet it is now seen that the younger generation of the country is trying heart and soul to develop the four skills of the English language. But the fact is that most of them do not get scopes for learning the language. There is paucity of teachers as well as shortage of appropriate institutions where people can learn English properly. Again there are some students who have no tendency to learn the four skills of English. They merely try to pass the English examinations. They have no mentality to master grammar, vocabulary and spelling. That is why Bangladesh is far away from India in terms of teaching and learning English. Regarding the decline of English in Bangladesh, Rahman (1999) mentions that Bangladesh faces the reality of falling behind the countries of her vicinity who are creating access to global market continuously. Despite the fact that the people of Bangladesh know the real value of English language, they do not have scopes and resources to master this language. To get rid of decline of English, all experts, specialists, linguists, academicians, and teachers must come forward in this regards.

\subsection{Frequent Changes of Policies about English}

For lack of a clear policy regarding English language teaching and its goal, different governments took different policies in this regard. In 1974, an education commission recommended that from class VI English should be taught as a second language. In 1976 according to the recommendation of the National Curriculum Committee, English was made compulsory from III. In 1983, there was another attempt to introduce English from class II and Arabic from class I which could not be implemented because of strong protest from the intellectual groups and political leaders. Then, in 1986, it was decided that English would be taught from class I as a compulsory subject (Rahman,1999).

The governments could not give any principles regarding the medium of instruction in secondary and higher secondary classes either. Until recently, both Bangla and English are being used as media of instructions in both 
the secondary and higher secondary levels of classes. Most of the teachers and students at the all levels of Bangladesh Education System are very weak in using the English language. The reason is that there is no precise policy regarding the teaching of English, and as such, there are limited scopes for learning the language. In terms of the English syllabus design, English language planning and policy must be developed. The government must try to look at the current global education policy and practice.

\subsection{English at the Tertiary Level}

Whether English would be taught in the tertiary level of education was also a subject of debate and changes. Until 1983, English was a compulsory subject for BA Pass Courses in Bangladesh. But, English was removed from the syllabuses of these classes by the then government in the year 1983 without any acceptable reason. Further in 1994 the incumbent government made English compulsory for BA Pass Course students to be implemented from 1995-1996 academic Session. In 1996 it was decided to teach English in university undergraduate classes (Rahman,1999).

So, English as language may be compulsory for all levels; there may be non-major English courses in different levels of education if necessary. We should try to come out of the current stalemate of English teaching and learning by placing English in its right place through a proper policy.

\subsection{Resort to English Medium Schools}

Because of the poor condition of teaching and learning of English in the mainstream education of the country a good number of affluent people resorted to the English medium schools which began to increase at a considerable fast rate. It has been observed that those who have English medium background and achieved degrees from private universities in the country or foreign universities are more competent users of English than those who have passed from Bengali medium educational institutions. And, as a result of having good command of English, people from English medium background started getting privileged and preferred in the job market.

\subsection{Training on English Language Teaching}

Like English language teaching policy, the training for English language teachers has also been neglected so long. Moreover, decisions regarding language teaching and learning were not taken by right people in this country. In this regards Rahman (1999) notes that "Policy decisions are in most cases taken by bureaucrats and educational administrators who may have very little understanding of what language is and how it is learnt." The students of the Secondary and Higher Secondary Levels of institutions greatly suffer from acute shortage of trained English teachers. In order to teach English one needs, in addition to language skills, the talent, know how and theories of language teaching so that one can make use of the best techniques to enhance one's students' learning process. Talented and innovative individuals capable of teaching English are valued and sought after in today's teaching assignments. To succeed in this competitive field, teachers perhaps need a solid grasp of grammatical concepts, and ought to know teaching skills, language acquisition theories, methods and demonstrate initiatives in the field. In approach, teachers should be able to put theories into practice in the classroom and work towards the goal of making the students learn English.

\section{Suggestions}

In order to achieve the goal of effective teaching of English probably the country needs a long term planning to implement some up to date policies. This may be done, firstly, by upgrading the Secondary Level English teaching capacity by reforming the teacher education which includes pre-service and in service training for English teachers because there has been a crying need for a time befitting and well-structured training programme for the English teachers of the Secondary Level in the country. Secondly, before taking any measures for improving the standard of the English language learning and teaching, the government may have a specific policy regarding the teaching and learning of the English language determining the objectives and goals to be achieved. Thirdly, as per Rahman (1999) in making policies and planning for language teaching, language teaching experts, bona fide language planners and competent teachers of English may be made involved.

\section{Conclusion}

It may be argued that planning language is planning inequality in socio-linguistic economic terms if one language is elevated at the cost of another language(s). Language Planning and policy are required for the greater interest of a nation. The English language as a subject is of paramount importance in equipping the students to take up the challenges of the competitive survival in the growing globalization. And, as the effect of language planning and policy is a long term one it is high time the people of Bangladesh realized that English, as a an international language, is a necessity for them and took proper initiatives to develop the learning and teaching of the English language in Bangladesh to a global standard. 


\section{References}

Arzoz, X., 'The Nature of Language Rights'. Journal on Ethnopolitics and Minority Issues in Europe (2007): pp. 23

Cooper, R. L. (1989). Language planning and social change. Cambridge: Cambridge University Press.

Crystal, D. (1995). The Cambridge Encyclopedia of the English Language. Cambridge: Cambridge University Press.

David.L. (2006). "Chinese as a lingua franca in Greater China”. Annual Review of Applied Linguistics. 26.149 176. $10.1017 / \mathrm{S} 0267190506000080$.

Hamid, M \& Erling, E. (2016). English-in-Education Policy and Planning in Bangladesh: A Critical Examination. 10.1007/978-3-319-22464-0 2.

Holmes, J. (2001). An Introduction to Sociolinguistics. England: Longman.

http://www.commonlii.org/bd/legis/const/2004/part1.html\#3. (18 May 2012)

Jernudd, B. (1981). Planning language treatment: linguistics for the third world. Language in Society 10:43-52

Kachru, B.B. (1996). South Asian English: Towards an identity in diaspora. In Baumgarder (ed.) 1996:9-28

Kaler Kantha. (2010). 21 February, p.18

Kaplan, R. B. and Baldauf, R. B. (2003). Language and language-in-education planning in the Pacific Basin. New York: Springer Publishing Company.

Mahbub, M. R. (2017). "State Language Movement and Bangabandhu Sheikh Mujibur Rahman". Bangladesh Awami League, http://192.185.67.22/ parbonc/index.php/updates/news/80-updates/articles/3464language-movement-and-bangabandhu-sheikh-mujibur-rahman Retrieved on 12 April 2019.

Rahman, A. (1999). English Language Teacher Education in Bangladesh:Towards and Alternative Pardigm. Ph.D. Thesis, University of London.

Rahman, A.M.M.H. (1999). "English Language Teaching in Bangladesh: didactics on the pragmatics of a language teaching policy", In Hunter (ed.) ELTIP Conference Proceedings: Dhaka British Council.

Robinson, D. (1988). "Language Planning and Policy." Eric Digest. ERIC Identifier: ED303051 Retrieved on 12 May 2019. https://www.ericdigests.org/pre- 9210/planning.htm

Rubin J, Jernudd B H. (1971). Can Language Be Planned? Sociolinguistic Theory and Practice for Developing Nations, M.A. Thesis. Honolulu: University of Hawaii Press

Rubin, J. (1971). Evaluation and language planning. In Joan Rubin and Bjorn H. Jernudd (Eds.), Can language be planned? Honolulu: The University Press of Hawaii.

Schiffman, H. F. (1996). Linguistic culture and language policy. London: Routledge.

Wardaugh, R. (1998). An Introduction to Sociolinguistics. Oxford: Blackwell Publishers Inc.

Weinstein. B. (1980). Language Planning in Francophone Africa. Language Problems and Language Planning, $4(1): 55-77$ 